http://dx.doi.org/10.4314/gjl.v6i3.1

\title{
MORPHOPHONOLOGICAL ANALYSIS OF AKAN FEMALE FAMILY-NAME FORMATION
}

\author{
Kwasi Adomako
}

\begin{abstract}
This paper examines the morphophonological processes in the derivation of some female family-names in Akan, a Niger-Congo (Kwa) language through the addition of a male source name and the female morpheme/-baa/. About three main kinds of family-names can be identified in Akan: (i) those usually given to females only, (ii) those gender-neutral, and (iii) those given to males but out of which female counterpart names can be derived. The current paper examines the third type and claims that even though different realizations of the female morpheme are observed, namely [-wa(a)], [-ma(a)], and [-a] to attach to the male source names, there is only one morpheme in the underlying presentation, that is, /-baa/, /-bea/, and /-ba/ for the Asante, Akuapem, and Fante dialects respectively, out of which these three variants are derived. This underlying morpheme manifests differently among the major dialects, which could be one of the points of distinction among them. To account for its different cross-dialectal realizations, it is shown in this paper that the underlying morpheme-initial consonant /-b/ specified for [+consonantal, +labial, -continuant] may acquire nasality at the surface level as in [-maa] through nasal place assimilation. The same consonant may lenite to labial glide [w] intervocalically and surfaces as [-waa]; or may even elide completely in the same context and be realized as [-a]; the underlying segment is systematically neutralized in the Asante dialect. In the Akuapem dialect, on the other hand, this underlying morpheme-initial segment is invariably fully preserved at the surface representation. The case of the Fante dialect resides in the middle of the continuum; i.e. it is non-systematic. The initial segment may or may not be preserved within the same contexts. Based on these observed variations it is concluded that while the other two dialects, especially the Akuapem, can preserve both the place and stricture features values of the underlying
\end{abstract}


morpheme-initial /-b/ of the female morpheme, the Asante dialect only preserves the value for the former, and systematically neutralizes that of the latter. This observation is formalized within the Optimality Theory.

Keywords: Akan, family-name, morphology, phonology, derivation.

\section{Introduction}

In the Akan custom, every child is given at least two personal names: the kradin, lit. 'soul name' i.e. 'day-name' and abusuadin 'family-name'. The former name is usually determined by the day on which one was born. The family-name, on the other hand, is given by the father's family. There are other formats in naming a child in the Akan traditional societies which shall be briefly mentioned in section 2 of the current paper. This paper examines the family-name of Asante, ${ }^{1}$ Akuapem (both Twi speakers), and Fante speakers of the Akan ethnic groups in Ghana with particular focus on those female familynames which are derived from male names through the suffixing of /-báá/, /-béá/, or /-bá/, the 'female' morpheme. The present paper analyses the morphological and the phonological processes of deriving such names and claims, on the basis of languageinternal evidence, that unlike in the Fante dialect, the female morpheme in the Twi dialects is not -bá from j̀bá 'offspring/child', but rather -báá originally òbáá2, which has only one meaning; 'female', which does not include the 'offspring/child' extended meaning, against earlier opposing views in the existing literature particularly Christaller (1933).

These derivational processes present one imperative way of distinguishing among the three major dialects of Akan. The difference between the two Twi dialects in this

\footnotetext{
${ }^{1}$ By Asante I do not refer exclusively to the ethnic group Asante, but by extension all other speakers of dialects of Akan which are often grouped under the Asante dialect in the literature, namely Bono, Kwawu, Akyem, etc. for literary purposes.

${ }^{2}$ My attention was drawn to the idea that even the morpheme sbaa 'female' itself seems to be derived from

$\mathbf{s b a}+(\mathbf{b a})$ wa through the deletion of the intervocalic $\mathbf{b} / \mathbf{w}$; and the male counterpart, sbarima could also be derived from $\mathbf{s} \mathbf{b a}+\mathbf{n i}(\mathbf{n i})+\mathbf{b a}$ through the application of an additional rule that changes $\mathbf{n}$ in $\mathbf{n i}$ to $\mathbf{r}$ in $\mathbf{r i}$ (see Boadi 1984 for the discussion of a similar rule in the formation of Araba 'Female Tuesday born' in Fante) by the Editor of this journal; my sincerest gratitude to him.
} 
formation is phonological, i.e. while in the Asante dialect some phonological alternations including intervocalic softening or lenition, nasal assimilation, etc. are observed, these processes do not apply in the Akuapem dialect at all. Fante, on the other hand, presents a different case; the lenition process is non-systematic. The same applies to the nasal place assimilation rule as compared to what obtains in the Asante dialect. Among the central aims of the present paper is to shed light on how learners of Akan can acquire this female family-name formation process in Akan. It will be observed that lenition is the most prominent phonological rule in the derivation process especially in the Asante dialect. It will be explained that the need for a rise in sonority on the scale results in the lenition process. It is claimed, in this paper, that in optimality-theoretic terms, there are some crucially-ranked markedness constraints in the Asante dialect such as *V\#CV that bans the initial plosive /b-/ from the surface level of representation. This same constraint, however, is completely demoted in the case of the formation of the names in the Akuapem.

The data for this study was collected from a list of registered undergraduate students offering BA (Twi) and BA (Fante) programmes in the Department of Akan-Nzema Education, College of Languages Education, University of Education, Winneba, between 2011 and 2015. The list comprises over 500 Akan family-names, which were purposively sampled for this study. The author purposively selected only female Asante, Akuapem and Fante family-names which are derived from their male counterparts. Where the author realized that not enough names were identified on the registered list of students, supplementary list of names was elicited from some students; this happened especially with the collection of the Fante family-names. To complement the list of family-names used in this study, I consulted some existing literature such as Christaller's (1933) Akan Dictionary and J.B. Crayner's (1988) book entitled, Yeehiahyia oo! lit. 'We have met (once again) oo!'. The latter book was very useful, especially for the collection of the Fante data. There were challenges with the orthographic convention of names where sometimes one name appears to end in variant forms as follows; <-waa $>,<-a a\rangle$, and $<-a>$ as in the following examples; darkowaa, darkoaa, and darkoa all representing the same name with the same phonetic realization. In such cases, I listened to some informants to settle on the common phonetic realizations of such names and in some other times, I resorted to my intuitions as a native speaker for such decisions.

The rest of this paper is organized as follows; section 2 presents brief background information about the Akan people and also their traditional naming practice. In section 3, an overview of the female/diminutive morpheme in Akan is provided where a separation of the female morpheme from the diminutive morpheme will also be argued for. I will 
briefly introduce the theoretical framework employed in this paper here also. The data presentation, discussion, and formalization are presented in section 4. In section 5 I summarize and conclude the discussions made in the paper.

\section{The Akan people}

Akan is a member of the Kwa (Tano Central) subgroup of the Niger-Congo language family, spoken mainly in Ghana and some parts of Côte d'Ivoire, both in West Africa. The language is spoken by the ethnic group called the Akan people in six out of the ten administrative regions in Ghana as their L1 (first language). According to Agyekum (2006), its dialects, which are mutually intelligible, include Asante, Akuapem, Akwamu, Fante, Akyem, Agona, Assin, Denkyira, Twifo, Wassaw, Kwawu, and Bron. Out of these, the three major dialects, which have received literary status in Ghana, are Akuapem, Asante, and Fante. The first two major dialects together constitute the Twi group. Statistically, together with its non-L1 speakers, it is estimated that far more than $50 \%$ of Ghana's over 24 million population ${ }^{3}$ either speak or understand the language. This arguably makes the Akan language the most widely used language in Ghana today for several purposes/functions.

\subsection{Akan naming practices}

According to Ossei-Akoto (2008), the Akan child is named after the day on which $\mathrm{s} /$ he was born in addition to a family-name that is given him or her by the father's family. This system of naming is unique to the Akan people though this practice has been adopted by several other ethnic groups in modern Ghana. Similarly, Agyekum (2006) also makes the same claim and in addition discusses other types of names such as event names, circumstantial names, birth number names, etc. Further references on the Akan naming practices are from Boadi (1984), Ansu-Kyeremeh (2000), Obeng (1997, 2001), Adomako (2015), among others. Brempong (1991) also talks briefly on this naming practice and the etymology of some Akan names including day-names; however, he fails to discuss the etymology of these names though he mentions them. In the present paper, however, I

${ }^{3}$ From the 2010 Population and Housing Census conducted, it is now estimated that Ghana's population is about 24.6 million. 
discuss how one type of the Akan family-name is derived and not necessarily the naming practice itself.

\section{The female vs. diminutive morphemes in Akan}

The earliest existing literature on diminution/female morphemes in Akan includes Christaller (1933), Boadi (1984), Dolphyne (2006) and Appah \& Amfo (2011). These works have attributed the original meaning of the diminutive morpheme ba to the full form oba 'offspring/child', which has extended meanings 'small, female, affection, etc., ${ }^{4}$ a claim this paper supports and of which expatiation would be made later on in the paper. However, it is worth noting that this present paper is not on diminution, but rather on the female family-name formation. A clearer distinction will be made from a similar female morpheme báá from the underlying word/morpheme j̀báá 'female' in subsection 3.1.

Christaller (1933) also makes a distinction between /-bá/ 'diminutive', derived from òbá 'offspring, child' and /-báá/ 'woman, female' derived from òbáá (1933: 1-2). However, he posits that, "it denotes also female gender" (1933: xxi). It is argued in the present paper that this assertion of the extended meaning of the morpheme is correct for whole formation processes in the Fante female family-names, but only partially so for the other two major dialects of Akan. To Christaller, one derives female names from the diminutive morpheme by simply adding /-a/ to it as he puts it, "...to indicate the female, when joined to a final a, wa is ...usually contracted into aa..." (1933: xxiii-xxiv). This statement is about the result of an intervocalic deletion of the liquid formed as a result which will produce the -aa. In section 4 , this liquid formation process through female family-name formation will be discussed. This process is usually termed lenition.

In discussing the formation of Akan female family-names, Christaller posits that "[f]emale names may be derived from male names by adding the word 'béá [originally from jbéá] or the termination (ba,) wa or ma, or by lengthening a final 'a'...” (1933: 602). Christaller's statement is not clear on the following grounds: first, the underlying form he posits is that of the Akuapem dialect which does not change its form in the formation of female (family) names at all hence, it does not have the so-called terminated forms. Second, the terminated forms he mentions seem to be associated with only the Fante dialect as the

\footnotetext{
${ }^{4}$ The assertion of the implicitness and the extension of the 'female' meaning is emphasized by Braun (2009:152) when she opines that "the Twi diminutive morpheme -wa/-ba, which originally comes from the noun sba 'child' differs from the Ewe and the Fon morphemes in that it renders the meaning 'female' additionally to the meanings 'young' and 'small'...".
} 
surface representation. Unless this statement is interpreted to mean that he was referring to the two separate dialects and how they form female names, it will be difficult to understand. Similarly, Boadi (1984) also posits that the morpheme -bá, which he asserts is found in all Volta-Comoe languages, stands for female or diminutive. However, just like his predecessors, he also mixes the two separate morphemes up by claiming that -ba is sometimes realized as -bea in the Akuapem dialect (Boadi 1984: 438).

If -bá is the underlying form, then by the statements above especially by Christaller (1933) and Boadi (1984), the implication is that the morphemes -bea and -ba are both from a common underlying morpheme/word, probably from j̀bá. This position raises some empirical issues as follows; (a) hypothetically how is -baa/-béá derived from an 'underlying' -ba? Is it through insertion? If yes, what then motivates such an a-insertion? Is it a templatic i.e. maximality constraint/requirement? Or (b) Is it a product of compensatory lengthening? And if yes, for what does this compensation require? A reversal postulation i.e. a claim of shortening or reduction of an 'underlying' -baa/-bea into -ba, on the other hand, might rather have more phonetic and phonological motivations. That is, articulatorily it is common and more economical for speakers to shorten a linguistic construction rather than to lengthen it except that the latter has some phonological appeal such as the satisfaction of some maximality or templatic requirement, which in this case does not seem to be the case. The question then is: what would motivate such a deletion? To avoid all these problems, two independent morphemes will have to be posited and clearly so from diachronic evidence or their etymology i.e. /òbá/ 'offspring, diminutive' and /òbáá/ or /òbéá/ 'female'.

Appah \& Amfo (2011) also make similar assertion that in the Asante dialect, female family-names are derived from the two separate underlying forms, though they admit they do not know how in some instances the reduced form ensues as they opine,

...Asante and Akuapem make use of suffixes from two sources for female names:(1) from (o)ba, the origin of the diminutive and (2) from obaa [sic], the Akan word meaning 'female'. The Akuapem equivalent of sbaa is obea,... We arrive at -waa from -baa through the same, yet not fully understood, the process by which the diminutive suffix becomes -wa from (o)ba (2011: 91).

While the view about the postulation of a common underlying form for the Akuapem female family-name formation is supported, an alternative analysis for the same process for the Asante dialect will be provided. It will be shown in this paper that just as in the Akuapem dialect, Asante also has only one underlying morpheme for deriving a female 
family-name, which is obaa 'female'. Hence, its different realizations are purely phonological and not lexical. The discussion of the diminutive and feminine morphemewa/-ba in Akan can also be referred from Dolphyne (2006: 85-86), though very briefly. In this present paper, an attempt will be made to provide data to emphasize their distinction both in form and in function and subsequent separation as a way of providing an alternative view to this assertion.

\subsection{Test for the independence of the bá and báá morphemes}

This distinction between the diminutive and female morphemes in terms of their form and meaning/semantic properties is straightforward in the Akuapem dialect i.e. /òbá/ 'offspring/child' and /òbéá/ 'female'. The same distinction is also made in the Asante dialect in j̀bá vs. òbáá. In the Fante dialect, however, the form/bàsíá/, ${ }^{5}$ which refers to 'female', is not employed as the female morpheme in such derivation, as it seems it rather collapses the meanings of the two morphemes into one form, i.e. /bá/ 'female, diminution'. This is why there are expressions such as the following;

\section{j̀bààbàsíá 'woman'}

The instantiation of the distinction between 'female' and 'diminution' in the Twi (Asante) dialect is made in the following nominal derivation in which the two morphemes co-occur.

\footnotetext{
${ }^{5}$ The compositional meaning of the word bàsía is not clear. Christaller (1933) does not know the etymology of the word j̀bàsía, but suspects it might have come through a proverbial construction, for which the earliest entry, according to him, was recorded in 1844 in constructions such as 'àkàtàasía', which is phonetically realized as [àkæ̀tæ̇ásíá] in the Twi dialect, etc. One of the earliest attempts to explain the composition of this word seems to have been made by Welmers (1946:49) when he glosses bá as young/child and the -sía in basia just as a bound morpheme.
} 
(2) Compounding of j̀báá and j̀bá morphemes

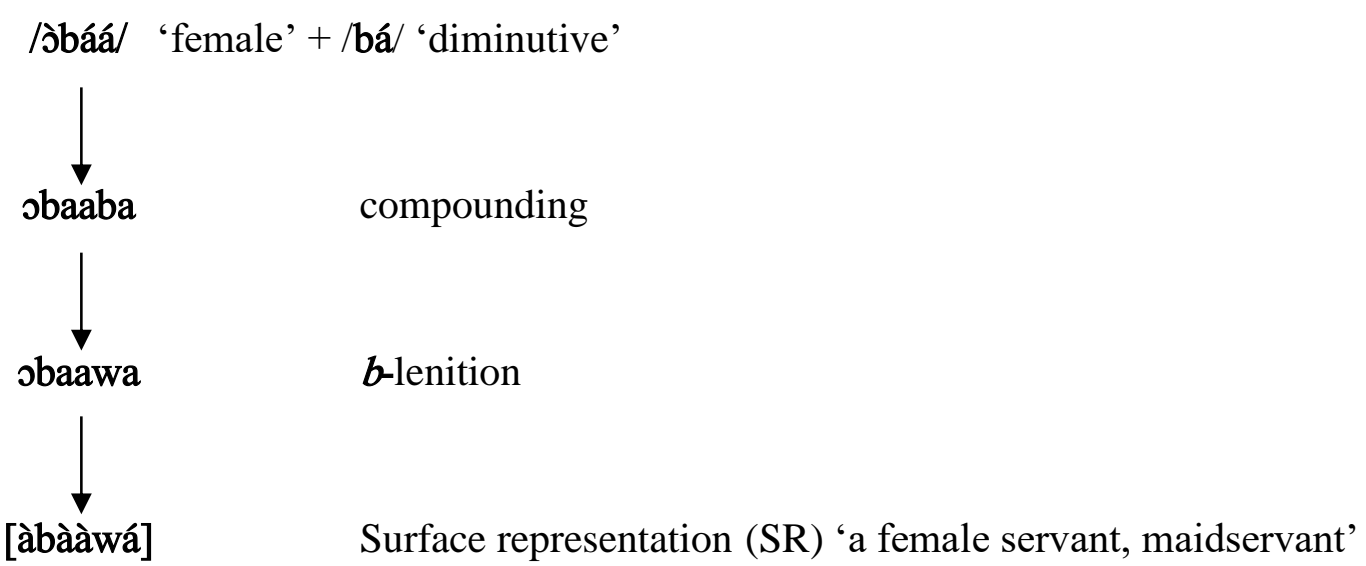

\subsection{Why the call for separate morphemes?}

One important question is why are the female counterparts of the day-names or Kradin i.e. soul names seem to use the 'offspring' morpheme bá while the family-names or Abusuadin employ the 'female' morpheme báá /béá among the Twi speakers.

Akradin lit. 'soul names' are very important names in the socio-cultural life of the Akan people. Among the Akan people, it is believed to be the name given to a person based on the day on which a person bids farewell to his/her Creator or the Supreme Being before sojourning or transiting to the earth from the spiritual world. That is why the female morpheme /báá/ is optional in Abusuadin, but /bá/ is invariable in all female kradin 'daynames'. It is worth emphasizing that the goal of this paper is not to answer or explain why some abusuadin are derivable while others are not, but to discuss how those that are derivable are derived in the language. I suppose future research would be able to provide a more adequate answer to this question.

I claim, following Christaller (1933), that while the Twi speakers employ the female morpheme -báá/-béá for the formation of female family-names and -ba for other names, Fante speakers use the morpheme -bá for all female personal names i.e. day-names and family-names. That is, Akan does not have a common morpheme for forming the two personal names i.e. day-name and family-name from male names as postulated in some existing literature, a point this paper will attempt to further expatiate. 


\subsection{The proposal}

I present a proposal for accounting for the female family-name in Akan below.

(3) bá-when [+animate] kradin = 'offspring', not diminution, could implicitly mean 'female'.

(4) bá-when [-animate $]=$ 'diminution', redundantly not 'offspring/female'

(5) báá/béá-selects for only [+animate] i.e. abusuadin 'female'.

Except one can convincingly argue that the underlying form òbáa 'female' is derived from òbá 'child/offspring', we cannot posit a common form and function for these two separate morphemes as the morpheme for the formation of female family-names among the Twi dialects of Akan.

Fante speakers, it is hypothesized, collapse (3) \& (4) in their form and meaning, ${ }^{6}$ which is semantically more economical but morphologically poor. This lends support to an earlier observation by Appah \& Amfo (2011: 91) that, “...in Fante names, the diminutive -ba (and what appears to be its intervocalic variant -wa/-ma) conflates the meanings of feminine and small'. Twi speakers, on the other hand, make use of the two distinct forms and their respective functions.

It is therefore concluded that the glossing format; 'female/diminution' is more appropriate for the Fante case only and not for Twi speakers. This paper will not belabour this issue much since it focuses on the morphological and phonological processes in the formation of the surface forms and not on the etymology of these names.

\subsection{Theoretical Framework}

In formalizing the discussions that will be made in the present paper, namely lenition and nasalization, I will employ the generative phonological tool; the Optimality Theory (henceforth OT) (cf. Prince \& Smolensky 1993; McCarthy \& Prince 1994; McCarthy 2002). The OT is a generative phonological theory that is guided by certain assumptions that linguistic grammar is embodied in an infinite universal set of violable

\footnotetext{
${ }^{6}$ It is worth pointing out that in Crayner's (1988) list of some indigenous Fante family-names, we observe exceptional derived female names such as Oforiwaa *Oforiwa, Adomakowaa *Adomakowa, etc. which look more like Asante than Fante as shall be seen in the section 4.
} 
constraints. These constraints are organized in a hierarchical order and are ranked; a particular ranking defines a particular grammar. Hence, every language has its unique set of ranking since there are no two languages that are the same. In other words, in OT, language A differs from language B based mainly on the variation in the rankings of the 'same' set of constraints by the two languages. The two main types of constraints are faithfulness constraints and markedness constraints.

Sometimes an output form may be required to map onto an input form in similitude (faithfulness constraints), while some other times the grammar would enforce some structural changes in an output form (markedness constraint) so that certain wellformedness requirements would be met in a particular manner. At all times these two sets of constraints are in conflict, and to ensure one of the several possibilities (output forms), which are termed candidates, emerges as the optimal or the most harmonic forms or the surface form. These surface forms, according to Kager (1999: xi), “... reflect resolutions of conflicts between competing demands or constraints." In the present paper, constraints from both the markedness and faithfulness sets of constraints will be employed for the analysis of the two main phonological processes observed in the formation of female family-names in Akan.

\section{Akan Female Family-Name Formation}

This section presents the data on the morphological as well as the phonological processes involved in the formation of female family-names from their male counterparts in Akan. It begins the discussions by briefly looking at some categories of family-names in Akan, specifically among the Twi speakers of Akan. Two major categories of familynames will be discussed, namely what would be non-derivable family-names and derivable family-names. The former will look at names that are usually given to either females only or those that are given to both males and females. The latter will focus on how female family-names are derived from the male counterparts, which will be the focus of this paper.

\subsection{Non-derivable Asante family-names}

By non-derivable Akan family-names, we refer to those family-names to which a female morpheme cannot be attached to derive a female version. Some of these names can be given to both males and females; others are exclusively female. I begin by looking at those names that are given to both males and females. 
It is worth pointing out that Ossei-Akoto (2008) classifies these names into exclusively male and exclusively female family-names. However, upon careful study, one realizes that virtually all the so-called exclusively male family-names can be given to females as well, therefore raising serious doubts about such classification. In this paper, I refrain from such classification and rather assume sex-neutral label for such names.

Again, it is worth noting that it should not be surprising to find female versions of this abusuadin. At first these non-derivable names were exclusively given to males in Akan, however, presently females are often given these per the naming practice in Akan. That is, once they do not have their female equivalents and a father who bears any of these names wants to name his child after him, the female child would eventually bear these names. Therefore, it is difficult and inappropriate for one to label the following names as exclusively male as Ossei-Akoto (2008) has sought to do. Below are some examples of these names.

(6) Common family-names for both male and female
a. Boama
b. Dankwa
c. Konadu
d. Agyeman
e. Bonsu
f. Adusee
g. Ahen
h. Adom $^{7}$
i. Sintim
j. Prempe
k. Pinaman

In (7) below, examples of some family-names that are exclusive to female Akan (Twi) speakers are provided.

\footnotetext{
${ }^{7}$ The female family-name Adomaa exists, however one should bear in mind that it is possible this name might have been derived from Adoma rather than Adom.
} 
(7) Common female family-names
a. Abrafi
b. Frema
c. Afrakoma
d. Birago
e. Bema
f. Biraso
g. Akyiamaa
h. Bommo

Again, the argument rages on as to whether these names have been derived from their male counterparts. However, unlike the names in (6), one can confidently posit that these names are exclusively female as it would be very odd, if not impossible, to find any male in the Akan society bearing any of these names. Again, it is worth restating that naming of a child in the Akan culture is a sole prerogative of the father and his family. This is not to say that a male child cannot be named after a female. When a male child is to be named after a female, usually a male counterpart of that female name, if available, is given to that male child. For a detailed discussion of these naming practices in Akan, see the references above. Below, I provide some of the non-derivable female family-names.

From the above, it then becomes very difficult for non-natives to categorically state which names are exclusively male and which are exclusively female. However, since this paper focuses primarily on the morphology and phonology of the formation of derived female abusuadin, I will not delve deeper into these name classifications as this falls outside the scope of the current paper. As was pointed out earlier, I will focus on that female abusuadin which have been derived from their male counterparts in the subsequent subsections.

In the subsequent sections, derivable female family-names whose derivation is done through suffixation of the female morpheme -baa, -bea, -ba shall be considered. I shall discuss the morphology and the phonology of such derivation and shall claim that all derived female family-names are systematically suffixed with /-baa/ or /-bea/ in the underlying representation in the Twi dialects, which manifests itself in about three different realizations at the surface representation in the Asante dialect specifically. However, in the Fante dialect, the underlying morpheme /-ba/ surfaces non-systematically depending on the context. 


\subsection{Derived Asante female family-names}

In this subsection, we look at the morphological and phonological rules through which some female family-names are formed from their male counterparts. Some of the phonological processes to be discussed will include $b$-softening or lenition, nasalization, and syllable reduction. The morphological rule to be studied, on the other hand, will be compounding of the female morpheme baa, bea, ba to the underlying male names in the derivation process. Before the discussions commence, it is necessary to explain what is meant by the expression, 'derived female family-name' as was done in the preceding subsection.

By the term derived female family-name, we simply refer to the female familynames which have been formed from their male source names through compounding them with the female morpheme /-baa/ or /-bea/ for the Twi speakers and/-ba/ for the Fante speakers.

\subsection{1. $b$-softening or lenition}

Lenition or $b$-softening is used here simply to refer to the process whereby a stop plosive, specifically $b$, becomes a liquid in a particular environment. Boadi (1984) employs the term; liquid formation, for this process in Akan, though Boadi (2009) refers to this same process as lenition. As has been pointed out already, the female morphemes Twi speakers employ to form female family-names out of male family-names are /-báá/ and /-béá/ in the Asante and Akuapem respectively. It is worth noting that the derived female family-names have the following template: 'male family-name + baa/bea'. These derived forms represent the output female family-names after the application of the necessary morphological and phonological rules. As a convention in this paper, those forms in the centre column are the output forms after the compounding process, the derived forms represent the output forms or the surface representation. In (8) below, the $b$-softening or lenition process will be illustrated with examples from Asante Twi. 
(8)

Underlying initial /-b/ lenites to [w] intervocalically

\begin{tabular}{|c|c|c|}
\hline Base forms & Compound form & Derived form \\
\hline a. àgyèí + báá & adkeibaa & àđèìwáá \\
\hline b. òfôrí + báá & oforibaa & òfôríwáá fôówáá \\
\hline c. àmòàkó + báá & amoakobaa & àmữầkứwáá àmũ̀ầkữãã \\
\hline d. tùtú + báá & tutubaa & tùtúwáá tùtuaáá \\
\hline e. kùsí + báá & kusibaa & kùsíwáá \\
\hline f. j̀scèe + báá & oscebaa & sèc̀wáá \\
\hline g. dàǹsó + báá & dansobaa & dàǹsưwáá \\
\hline h. nyáńtàkyí + báá & jantatcibaa & jấńtæ̇tçiwáá \\
\hline i. kyèí + báá & tceibaa & tcèíwáá ～tcèéwáá \\
\hline j. kùmí + báá & kumibaa & kùmíwáá \\
\hline k. òhéné + báá & ohenebaa & ̀̀hî́nî́wáá \\
\hline 1. àsàǹté + báá & asantebaa & àsã̀ǹtíwáá àsã̀ǹtúáá \\
\hline m. òdúrò + báá & odurobaa & dùròwáá òdùráá ${ }^{8}$ \\
\hline n. àdú + báá & adubaa & æ̀dúwáá \\
\hline o. àfràné + báá & afranebaa & àfrã̀nî́wáá \\
\hline
\end{tabular}

(9). Rule 1: Lenition or $b$-softening rule in the Asante:

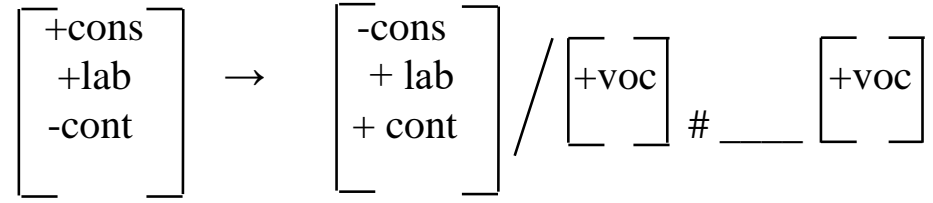

From (9), we realize that there is no feature change between the underlying form and the surface form but only change in feature values in their respective feature matrices. For example, while the value for the feature [cons] in the underlying form is a plus, it is a minus in the surface segment. Conversely, while the value for the feature [cont] is a minus in the underlying form, it is plus for the surface representation. However, both the underlying form and the surface form have the same value for the feature [lab], which is a plus. The rule in (9) applies in all such contexts in the Asante dialect. That is, an underlying

${ }^{8}$ From my personal investigations, forms such as [òdùráá] and [tç̀ráá] are common among the Kwawu ethnic group, while the Asante counterparts are [dùròwáá] and [tç̀réwáá] respectively. 
morpheme-initial /b-/ surfaces as the glide [w] after vowels. The intermediate (i.e. postcompound) level forms at which this lenition rule fails to apply in this context never surfaces in the Asante dialect, but as shall be seen later in this paper, are the forms expected to surface in the Akuapem dialect and to some extent in the Fante dialect as well.

\subsubsection{Formalisation of lenition in the Asante female family-name}

To account for the lenition process discussed above, it was observed that in terms of features, one observation was obvious, namely that the labial place feature is maintained throughout the derivation processes. That is, the input [labial] feature never surfaces as non-labial in the output form. This is accounted for by positing a faithfulness constraint IDENT-IO. We will have two forms of this constraint; one that demands correspondence between the input and the output in terms of place feature, and the other that demands correspondence in terms of manner, which is this case is the feature [continuant]. The former has to outrank the latter in that as was concluded from the discussion of the examples in (8), there is always a correspondence between the input and the output in place feature but not in manner feature. These constraints are therefore defined as follows.

(10) IDENT-IO(Cont): Correspondents in input and output have identical value for the feature [cont]

(11) IDENT-IO (PI): Correspondents in input and output have identical place features. (cf. Kager 1999: 132)

The constraint in (11) is undominated since all output forms, whether the lenition rule applies to them or not, must satisfy this high-ranking constraint because the labial place feature must be preserved in all candidates than to preserve the manner of articulation contrast. It has to dominate IDENT-IO(cont).

A constraint to ban the initial $\mathrm{C}$ of the underlying - CVV morpheme - baa from the surface representation is needed. This constraint will ensure that the consonant is neutralized and as has been discussed already, such neutralization is achieved through lenition. The context of the application of the lenition rule is crucial in the formulation of this featural well-formedness constraint. The context, as we have seen, is when the target consonant is preceded by a morpheme-final vocalic segment at morpheme boundary. We will formulate this constraint $* \mathrm{~V} \# \mathrm{CV}$, where $\mathrm{C}$ is specified for [+cons, +lab, -cont] and define it as follows. 


\section{*V\#CV:}

An initial C specified for [+cons, +lab, -cont] is prohibited when preceded by $\mathrm{V}$ at morpheme boundary.

This markedness constraint has to be dominated by the faithfulness constraint IDENT-IO (Pl) since preserving the place feature of the input $\mathrm{C}$ is more crucial than neutralizing its manner feature. Therefore, the consequence of violating IDENT-IO(P1) will be costlier than to violate $* \mathrm{V \# CV}$.

There also has to be a constraint that penalizes a candidate that resorts to deletion in order to satisfy $* \mathrm{V \# CV}$ instead of altering values of some features as was seen to be the case in the Asante dialect. This anti-deletion constraint is MAX and it is defined as follows.

(13) MAX-IO: Every segment of the input has a correspondent in the output.

A relatively high-ranking of MAX-IO will ban segment-deleting candidates from emerging as optimal. It has to outrank $* \mathrm{V \# CV}$ since deletion is not a strategy to avoid that well-formedness constraint, but it is to be dominated by IDENT-IO(Pl).

Tableau 1: Analysis of intervocalic lenition or b-softening in the Asante

\begin{tabular}{|l|c|c|c|c|}
\hline /ofori + baa / & $\begin{array}{c}\text { IDENT- } \\
\text { IO(Pl) }\end{array}$ & MAX-IO & $* \mathrm{~V} \# \mathrm{CV}$ & $\begin{array}{c}\text { IDENT - } \\
\text { IO(cont) }\end{array}$ \\
\hline \hline a. oforibaa & & & $* !$ & \\
\hline b. ${ }^{\circ}$ oforiwaa & & & & $*$ \\
\hline c. oforimaa & & & $* !$ & \\
\hline d. oforiaa & & $* !$ & & \\
\hline
\end{tabular}

\section{Ranking: IDENT-IO(Pl), MAX-IO »*V\#CV »IDENT-IO(cont)}

Candidate (d), which resorts to deletion in order to satisfy a relatively high-ranking $* \mathrm{V \# CV}$, is the least harmonic candidate for fatally violating a higher-ranked MAX-IO, though it satisfies the undominated constraint in this ranking; IDENT-IO(Pl). Candidates (a) and (c), though are faithful to the input, falls out of the competition as a result of the violation of the crucially-ranked constraints; *V\#CV that bans the [-cont] stop in $\mathrm{CV}$ syllable when preceded by a $\mathrm{V}$ at morpheme boundary in the output a constraint satisfied by the optimal candidate (b). Though both candidate (a) and candidate (c) violate once only one constraint and also satisfy IDENT-IO(cont), a constraint violated only by candidate 
(b), the low ranking of IDENT-IO(cont) makes its violation the least offensive in this tableau, hence the preference for (b) as the optimal candidate over both (a) and (c).

\subsubsection{Nasalization rule}

In the formation of female family-names in the Asante dialect, whenever the base male name is nasal final, the female morpheme-initial /-b/ tends to surface as bilabial nasal $[\mathrm{m}]$ in the derived female name. There are few exceptions to this nasal assimilation rule which shall be discussed later in this section. This nasal assimilation process is exemplified in (15) below.

(15) Underlying initial /-b/ assimilates to [m] after nasal stop

\begin{tabular}{|c|c|c|c|}
\hline Base forms & $\underline{\text { Compound form }}$ & $\underline{\text { Nasal assimi }}$ & Derived fo \\
\hline a. sàpòǹ + báá & saponbaa & sàpòm̀mmáá & sàpõ̀mãã \\
\hline b. áḿnp̀̀̀ + báá & amponbaa & àm̀ेp & mã̃á \\
\hline c. àmòátéń + báá & àmòátéńbáá & àmùátímmmáá & àmữấț̣̂mã̃a \\
\hline d. àmòànín + báá & amoaninbaa & àmùànímmmáá & àmừằnimẫá \\
\hline kwàátéń + báá & kwaatenbaa & kwàátímmáá & kª̀átî́mã̃á \\
\hline bóátéń + báá & boatenbaa & bưátímmááá & bưátímããa \\
\hline frì̀̀mpóǹ + báá & frimponbaa & ómmmáá & frìmpònmã̃á \\
\hline 1. àgyàpśǹ + báá & agya & ómmmáá & àđàpṍmã̃á \\
\hline bòàhèǹ + báá & boahenbaa & bùàhìm̀máá & bùàhî̀mấá \\
\hline àkyéáḿpòǹ + báá & akyeamponbaa & ว̀̀̀mmáá & วั̀m \\
\hline gyáǹ + béá9 & danbea & dàm̀mméá & dàn \\
\hline bòsòm̀ném + báá & bosompembaa & bùsùmònímmáá & bùsùmìñ̂̃mã̃ã̃ \\
\hline $\begin{array}{l}\text { pìpím }+ \text { b } \\
\text { bóákóḿ }+\end{array}$ & pipimbaa & pìpímmáá & hと̛́์ \\
\hline & & b & \\
\hline
\end{tabular}

It can be seen from the examples in (15) that at the SR, all the pre-nasal vocalic segments get nasalized before they trigger the nasal i.e. the final nasal of the female name is deleted hence, the realization of only one $[\mathrm{m}]$ in the surface forms. Of particular interest

\footnotetext{
${ }^{9}$ This is originally a Bono name with Akuapem female morpheme. It undergoes manner assimilation process discussed in Rule 2 in its derivation contrary to what actually obtains in a typical Akuapem female familynames formation process. This seems to be the Asante version of the Akuapem form gyanbea.
} 
is the fact that the same $/ \mathrm{m} /$ is what is usually observed in the orthography. This observation is schematized in the following linear rule.

(16). Rule 2- Nasal assimilation rule in the Asante:

$$
\left[\begin{array}{l}
+ \text { cons } \\
+ \text { lab } \\
\text {-cont } \\
\text {-nas }
\end{array}\right] \rightarrow\left[\begin{array}{l}
+ \text { cons } \\
+ \text { lab } \\
- \text { cont } \\
+ \text { nas }
\end{array}\right] /\left[\begin{array}{l}
+ \text { nas } \\
+ \text { cons }
\end{array}\right] \#
$$

From (16), first, we observe that there is an additional feature; [nasal] which is added to the previous features we employed for Rule 1. This will enable us to account for the nasal feature assimilation we observed in the examples in (15). Second, upon a careful look at Rule 2, one observes that both the underlying form and the surface form share all features and values together in their feature matrices except in the value for [nas] which is a minus in the underlying form and a plus in the feature matrix of the surface form. From OT perspective, as we shall soon see, the output form that changes input $/ \mathrm{b} /$ to $[\mathrm{m}]$ demonstrates maximal faithfulness to the input.

\subsubsection{Formalisation of nasal assimilation in the Asante female family-name}

By employing the same set of constraints as previously in tableau 1 for the present analysis, a suboptimal candidate is likely to emerge as the harmonic candidate since this section analyses a different phonological process; nasalization. This will be illustrated in the following Tableau 2.

Tableau 2: Analysis of nasal assimilation in the Asante

\begin{tabular}{|l|c|c|c|c|}
\hline / sapon + baa / & $\begin{array}{c}\text { IDENT- } \\
\text { IO(Pl) }\end{array}$ & MAX-IO & $* \mathrm{~V} \#$ CV & $\begin{array}{c}\text { IDENT - } \\
\text { IO(cont) }\end{array}$ \\
\hline \hline a. saponbaa & & & $* !$ & \\
\hline b. $\odot$ sapommaa & & & $* !$ & $*$ \\
\hline c. ${ }^{\varpi}$ saponwaa & & & & $*$ \\
\hline d. sapowaa & & $* !$ & & $*$ \\
\hline
\end{tabular}


From Tableau 2, candidate (c), which is a suboptimal candidate, emerges as the most harmonic candidate for satisfying all the important constraints in the ranking hierarchy at the expense of candidate (b). To address this, we will need constraints that will account for the nasalization process that the expected optimal candidate has undergone. These constraints should ensure that /-b/ agrees with the preceding morpheme-final nasal in terms of nasality, hence the feature [nas]. These constraints could be taken from Agreement family of constraints. The two additional specialized constraints from the Agreement family that will be needed are defined as follows.

(17) AgreE(nasal): $\quad$ Segments agree in terms of manner feature [nasal].

(18) AGREE(pl): $\quad$ Segments agree in terms of place feature.

The two constraints in (17) and (18) have to be dominated by IDENT-IO(Pl), but they must dominate IDENT-IO due to the fact present in tableau 1 where the input morpheme-initial /b/ never surfaces in the Asante dialect. And also owing to the fact that irrespective of the neutralization process this initial stop undergoes, its labial place feature is invariably preserved in the output forms.

\subsubsection{Re-analysis of nasalization in the Asante female family-name}

In this subsection, the tableau analysis that was made in tableau 2 where a suboptimal candidate emerged is reconsidered with the introduction of two additional constraints.

Tableau 3: Re-analysis of nasal assimilation in the Asante

\begin{tabular}{|l|c|c|c|c|}
\hline / sapon + baa / & $\begin{array}{c}\text { IDENT- } \\
\text { IO(Pl) }\end{array}$ & AGREE(nas) & AGREE(pl) & IDENT -IO \\
\hline \hline a. saponbaa & & $* !$ & $*$ & \\
\hline b. sapommaa & & & & $* *$ \\
\hline c. saponwaa & & $* !$ & $*$ & $*$ \\
\hline d. sapowaa & & $* !$ & & $*$ \\
\hline
\end{tabular}




\section{Ranking: IDENT-IO(Pl), AGREE(nas), AGREE(Pl) »IDENT-IO}

From tableau 3, both candidates (a) and (d) fall out of the competition for fatally violating highly-ranked AGREE(nas), which demands the morpheme-final nasal $/ \mathrm{n} /$ and the morpheme-initial /-b/ share the nasal feature at the juncture. Candidate (c) on the other hand, also incurs a fatal violation mark for the other type of the AGREE constraints; AGREE(Pl) that enforces sharing of place feature between the two morphemes. Though candidate (b) violates IDENT-IO twice; one for labializing the morpheme-final alveolar nasal $/ \mathrm{n} /$ of the male family-name, and one for nasalizing the female morpheme-initial $/ \mathrm{b} /$, it emerges as the optimal candidate due to the fact that this violation is of minimal effect to affecting its optimality.

\subsubsection{Exceptions to the nasalization rule}

It is not in all contexts in the formation process that the expected nasalization rule applies in the Asante dialect. There are few exceptional cases to the nasalization rule stated above in (16) above. This is where the postnasal /b/ is realized as $[\mathrm{w}]$ and not [m] as would be expected. This is illustrated in (20) below.

(20) Failure of nasalization in the Asante
$\underline{\text { Base forms }}$
àfúmìáá
b. twúm + báá
twúmònáá
àgyèkúm̀̀báá
ànímbáá
d. àním + báá
àdútwùmbáá
e. àdútwù̀̀ + báá
f. ànín + báá
ànímbáá
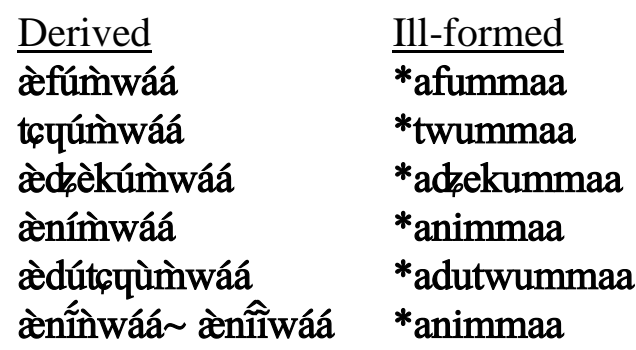

The ungrammatical forms to the extreme right are the expected forms per Rule (2); however, they never surface in the Asante Twi dialect. In the examples above, it is observed that the liquid formation process becomes the last step in the derivation and not the subsequent expected homorganic nasal assimilation.

In order to account for such exceptions, we may have to resort to some diachronic facts to determine whether the base forms are actually nasal-final in the underlying representation or vowel-final, following the claims in some existing literature that all final 
nasals in Akan were diachronically followed by high vowels (cf. Abakah 2004, etc.). If this claim holds for the personal name formation in Akan, then one can explain phonologically that in the derivation process, perhaps the glide formation rule applies before those 'elided' final vowels are deleted at the intermediate level, hence the realization of the sequence of the nasal and labial glide at the surface representation in the examples in (20). However, the question that arises from this postulation then is, why do these examples behave differently from the very similar ones discussed in (15)? This is an open issue and the explanation for this failure might reside in the etymology of these names which would be outside the domain of morphophonology.

From hindsight, it may look simple for one to challenge the invariability of the lenition or $b$-softening rule claim made so far in this paper citing the facts of these exceptional cases. However, by positing that there are two independent rules that usually apply in Asante, we are able to account for the invariability of the lenition rule, but it is the nasalization rule which is non-systematic in its application. By this, it can be posited that two main phonological processes apply in the Asante female family-name formation, namely; (a) lenition and (b) nasalization. And that while (a) is systematic irrespective of the context, (b), on the other hand, may fail to apply though the environment would be there for its application. ${ }^{10}$

\subsubsection{Reduction in the female morpheme -baa}

There are instances of irregularities in the formation of female family-names in the Asante dialect where the initial consonant of the female morpheme is deleted, thereby reducing the full underlying morpheme to either $[-\mathrm{aa}]$ or $[-\mathrm{a}]$ at the surface representation. This is exemplified in (21).

\footnotetext{
${ }^{10}$ Could this failure be classified as an instance of underapplication of nasalization, after a similar process of failure of palatalization rule in Akan reduplication? (cf. Marantz 1982, McCarthy \& Prince 1994, 1995, among others).
} 


\begin{tabular}{|c|c|c|c|c|}
\hline Base form & Compound form & $\underline{b \text {-deletion }}$ & Derived form & Ill-formed \\
\hline àdòmá + báá & àdùmábáá & àdùmá-áá & àdùmã́-ã̃ & *àdùmáwáá \\
\hline yàǹkyérà + báá & jàntçíràbáá & jàǹtçírá-áá & jàǹtḉrá-á & *jàǹtçìráwáá \\
\hline gyìmá + báá & dà̀mábáá & dqìmà-áá & dò̀mã́-ã́ & *doìmàwáá \\
\hline àm̀̀pòǹsá + báá & àm̀̀pòǹsábáá & àm̀̀pòǹsá-áá & àmòpồǹsã́-ã́ & *àm̀npõ̀ǹsấwáá \\
\hline àǹsá + báá & àǹsábáá & àǹsá-áá & ànssã́-ã́ & *àǹsấwáá \\
\hline
\end{tabular}

In the formation of the female family-name in (21) above, we posit a deletion of the morpheme-initial /-b/ after the compounding stage. This deletion process then results in a marked structure of the sequence of three vowels $-\mathrm{V}_{1} \#-\mathrm{V}_{2} \mathrm{~V}_{3}$ in a personal name in the surface representation (except in some syntactic constructions such as the completive form of say, hunu 'see' in shunuuie 's/he saw (it)'). Such sequence has been observed to be permitted in Akan personal names only at the juncture of two separate personal names said in a fast speech, and even that, such a sequence is as a result of compensatory lengthening (cf. Adomako 2015). This sequence can be of the same vowel quality, as in the examples above (under ' $b$-deletion'), or of two different qualities between the $\mathrm{V}_{1}$ - and the remnant $-\mathrm{V}_{2} \mathrm{~V}_{3}$ of the female morpheme. As a repair mechanism for this, either one of the remnant vowels will further be dropped when they are of the same quality as the $V_{1}$. On the other hand, where the quality of the $V_{1}$ is different from the remnant vowels, the $V_{2}$ will coalesce with the $V_{1}$ at the juncture. Example of such cases for the latter is in the formation of toira-a from tcire + baa.

To account for this in OT, the same set of constraints employed in our analysis in subsection 4.2.1.1 will be needed here. However, unlike in that analysis which focused on feature value change, this time around the focus here in on structural well-formedness and the strategy to ensure that has been observed to be the deletion rule. To allow deletion to take place, MAX-IO, which was highly-ranked in the previous tableau, needs to be demoted significantly so that its violation will not significantly affect the optimal candidate. And just as has been seen in (21), deleting only the initial /-b/ will result in a marked V\#VV sequence in a singleton personal name. The constraint to penalize such illicit sequence, in this case, will be *VVV. This constraint has to rank above MAX-IO for the fact that deleting the initial consonant is less costly than allowing the sequence. I define $* \mathrm{VVV}$ as follows.

(22) *VVV:A sequence of three or more contiguous vowels within a morpheme is prohibited. 
The use of the morpheme to define the domain of the prohibition of the sequence is in reference to the fact that at the surface level, though the claim in this paper thus far is that these female family-names are bi-morphemic in the underlying representation, they surface as one morpheme.

\subsubsection{Formalisation of morpheme - baa reduction in the Asante female family-name}

In this subsection, the cases of the reduction of the female morpheme -baa in forming some Asante female family-names. I will need to re-rank some of the constraints used in 4.2.1.1 to account for this process as below.

Tableau 4: Analysis of the reduction of the female morpheme -baa in the Asante

\begin{tabular}{|l|c|c|c|c|c|}
\hline / ansa + baa / & $\begin{array}{c}\text { IDENT- } \\
\mathrm{IO}(\mathrm{Pl})\end{array}$ & $* \mathrm{V \# CV}$ & $\begin{array}{c}\text { IDENT - } \\
\text { IO(cont) }\end{array}$ & $* \mathrm{VVV}$ & MAX-IO \\
\hline \hline a. ansabaa & & $* !$ & & & \\
\hline b. ansawaa & & & $* !$ & & $* *$ \\
\hline c. ? ansaa & & & & & $*$ \\
\hline d. ansaaa & & & & $* !$ & \\
\hline
\end{tabular}

\section{Ranking: IDENT-IO(Pl), *V\#CV»IDENT -IO(cont) »*VVV» MAX-IO}

From tableau 4, both candidates (a) is the worst among the possibilities in the tableau because of its fatal violation of the highly-ranked $* \mathrm{V \# CV}$, though that is the only constraints it violates. Candidate (b) follows (a) in being ruled out of the competition for incurring a fatal violation mark for the crucially-ranked constraint; IDENT-IO(cont), a constraint that enforces the output forms to maintain the input value for the feature [continuant]. The competition for the optimality then falls between the candidate (c) and the candidate (b), both of which employ deletion to avoid violation *V\#CV. By so doing, these two are the only candidates that violate the anti-deletion constraint MAX-IO. Though candidate (c) violates MAX-IO twice vis-à-vis once by its closest competitor; (d), it emerges optimal at the expense of (c) for satisfying a deciding constraint; *VVV which candidate (c) violates albeit once. 


\subsection{Female family-name formation in the Akuapem}

In the Akuapem dialect, basically, a straightforward as well as a systematic formation pattern is observed in its female family-name. That is, it goes through the morphological process of affixation. However, all the three additional phonological processes so far discussed to apply in the Asante are deactivated in the Akuapem case. In other words, the derivation process in Akuapem is basically morphological i.e. simple compounding. I exemplify this in (24).

Underlying initial /-b/ surfaces as [b]
$\underline{\text { Base form }}$
Derived form
$\underline{\text { Ill-form }^{11}}$
a. j̀féè + béá
òfềibíá
b. àgyèí + béá
æ̀đèíbíá
c. sákyì + béá
sæ̇tcìbíá
d. àsá + béá
àsàbíá
e. àdú + béá
æ̀dúbíá
f. àdò + béá
àdưbíá
g. àgyèkúm + béá
æ̀đèkúmìbíá
*oferwIa
*ædeiwia
*sætciwia
*asawia
*aduwia
*aduwia
h. gyán + béá
đáñoíá
*ædekummia
*daanwia/dqammia

From the examples above, the phonological processes, namely lenition, nasal assimilation, and syllable reduction, which we observed applied in different contexts in accounting for the formation of the female family-names in the Asante, do not apply at all in the Akuapem case. For example, the lenition rule fails to apply in (24a) - (24f), while the nasal place assimilation also does not apply in $(24 \mathrm{~g})-(24 \mathrm{~h})$. The only common process the two dialects share is the compounding of the two morphemes. This non-application of

\footnotetext{
${ }^{11}$ It is worth noting that the ill-forms in the Akuapem derived female family-names are possible and acceptable names in the Asante dialect; the initial plosive of the second morpheme would have undergone the lenition or liquid formation process in that context as have been discussed earlier in this paper. One exception to this generalization is the female family-names such as Oforiwaa *Oforibea that exist among Akuapem speakers. It is plausible to posit that this name might have been wholly adopted directly from the Asante stock as the male counterpart Safori, and not Ofori, is rather common among Akuapem speakers just as was hypothesized that [dammĩã] might have originated from the Bono's [cammãã] and adapted into Akuapem as [d;anbia] and then finally back to Bono as [dammĩa] .
} 
those phonological rules makes the Akuapem process phonological poor, its formalisation, though becomes straightforward which I do in the following subsection.

\subsubsection{Formalisation of the Akuapem female family-name}

In accounting for the female family-name formation in Akuapem, one has to simply re-rank the last two constraints of the ranking in (14). That is, IDENT-IO(cont) has to outrank $* \mathrm{~V} \# \mathrm{CV}$. The output in Akuapem, unlike in the Asante dialect, is systematically faithful to the input. I present the analysis showing candidates that do not apply lenition and nasal assimilation are rather preferred in Akuapem in tableau 5 below.

Tableau 5: Analysis of the Akuapem female family-name formation

\begin{tabular}{|c|c|c|c|c|}
\hline 1. / sætci + bra / & $\begin{array}{c}\text { IDENT- } \\
\text { IO(Pl) }\end{array}$ & MAX-IO & $\begin{array}{c}\text { IDENT - } \\
\text { IO } \\
\end{array}$ & $* \mathrm{~V} \# \mathrm{CV}$ \\
\hline a. sætcibia & & & & $*$ \\
\hline b. sætciwaa & & & $* !$ & \\
\hline c. sætciwıa & & & $* !$ & \\
\hline d. sætcira & & $* !$ & & \\
\hline \multicolumn{5}{|l|}{ 2. /ædekum + bra/ } \\
\hline \multicolumn{5}{|l|}{ a. ædekumbia } \\
\hline b. ædekummıa & & & $* !$ & \\
\hline c. ædekumwaa & & & $* !$ & \\
\hline d. ædъekumıa & & $* !$ & & \\
\hline
\end{tabular}

\section{Ranking: IDENT-IO(Pl), MAX-IO » IDENT-IO »*V\#CV}

In Tableau 5, IDENT-IO has been left non-specified for any feature in order to be able to account for the different cases of mismatch between the segments in the input and those of the output. For example, the analysis in 1 of Tableau 5, IDENT-IO could refer to the manner feature [continuant], while in 2 it can also refer to the feature [nasal]. In summary, by promoting the Input-Output faithfulness constraints while demoting the structural well- 
formedness constraint(s) at the same, it will result in the emergence of faithful outputs, which is the case in Tableau 5. The optimal outputs in both analyses truly reflect the forms in Akuapem.

In the following subsection, a similar formation process in the Fante dialect will be briefly discussed. Unlike the case of Akuapem, lenition and nasalization rules apply nonsystematically in the Fante dialect. This is expatiated in subsection 4.4.

\subsection{Female family-name formation in Fante}

The derivation of the female family-names in Fante presents another interesting scenario. Three contexts in the formation processes are discussed in this subsection. The first context is where the female morpheme occurs before high vowels. The second is where the female morpheme occurs before non-high vowels. The third context is where the same morpheme is preceded by non-vowel sonorants.

Just like the lenition example that was considered for the Asante dialect, it is observed the same process in the Fante dialect as well. However, unlike the Asante example, the Fante case seems to be highly context-defined. That is, it systematically applies whenever the final vowel of the source male family-name is specified for [+high]. The morpheme-final vowel of the underlying male family-name is underlined for emphasis.

(28) Underlying initial /-b/ lenites to [w] when preceded by [+high]

\begin{tabular}{|c|c|c|}
\hline Base forms & Compound form & Derived form \\
\hline a. èdú + bá & èdúbá & èdúwá \\
\hline b. sèkyì + bá & sèkyìbá & sètcìwá \\
\hline c. gyèsí + bá & gyèsíbá & ḑèsíwá \\
\hline d. kwèntsí + bá & kwéńtsíbá & $\mathbf{k}^{\mathbf{w} e ̀ n ̃ t s i ́ w a ́ ~}$ \\
\hline e. dádzìè[ááczì]+bá & dádzèbá & àdààdíwá \\
\hline f. bùdù + bá & bùdùbá & bùdùwá \\
\hline g. òbósù + bá & òbósùbá & òbósùu!wá \\
\hline h. sègú + bá & sègúbá & sègúwá \\
\hline i. áyéńsú + bá & áyéńsúbá & ájéńsúwá \\
\hline j. kwèenú + bá & kwèénúbá & 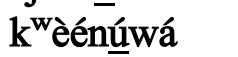 \\
\hline k. pèńtsí + bá & pèńtsíbá & pèńtsíwá \\
\hline 1. áfènyí + bá & áfènyíbá & áfèyî́wá \\
\hline
\end{tabular}



m. èsíèdú + bá
èsièdúbá
èsièdúwá
n. àmàmòni + bá
àmàmfíbá
àmàmòíwá
o. bèényí + bá
benyinbá
bèénî́wá

From the examples in (28), we see clearly the lenition process which we observed in the Asante data applies here as well. That is, before a morpheme-final V, morphemeinitial /-b/ lenites to [w]. The difference between the two cases, however, is that in the Fante, the preceding vowel is specified for [+high] while it was not specified at all in the Asante case. From the Fante data, this context systematically triggers the lenition process. However, there are other contexts in which the process still applies where though the preceding $\mathrm{V}$ is non-high as can be seen in the following examples in (29) below.

(29) Underlying intervocalic/-b/ lenites to [w] when preceded by [-high]
$\underline{\text { Base forms }}$
Compound form
a. édúà + bá eduaba
Derived form
éduíầá
bàáwá
$\underline{\text { Ill-formed }}$
b. bàá + bá
baaba
sáàwá sáàbá
*eduaba
c. sáà + bá
saaba
d. àmoéà + bá
ampeaba
àmò̀ìàwá àmònìàbá
e. èsáńdò + bá
esandoba
èsáńdòwá
*baaba

More complicated is the case where the lenition process fails to apply in very similar contexts as described above in (29) i.e. before non-high vowels. I provide examples in (30) for illustration.

Failure of lenition
$\underline{\text { Base forms }}$
Compound form
Derived form
$\underline{\text { Ill-formed }}$
a. m̀̀bòró+bá
mborobá
m̀̀ừóbá
apaaba
àpàábá
*mborowa
b. àpàá + bá
yamoaba
jámúàbá
d. m̀̀bèá + bá
mbeaba
m̀̀bìàbá
*apaawa
*yamoawa
*mbeawa

The third case in Fante where nasal assimilation seems to follow that of the Asante in (31), but at the same time in similar context fails to apply as can be seen in the following examples in (32). It is worth pointing out that the examples in (31) do not seem usual of the Fante dialect of Akan which does not usually apply nasal place assimilation. If anything 
at all, we would expect Fante names to behave like those in (32). I suppose a detailed investigation into this phenomenon will be required to explain this particular pattern. The question is, are there really three separate female morphemes in Fante at the lexical level?

Nasal assimilation in Fante
$\underline{\text { Base forms }}$
Compound form
a. j̀bén + bá
sbenba
b. ǹtsén + bá
ntsenba
c. áhèn + bá
ahenba
d. kwàánsá + bá
kwaansaba

Derived form
òbî̀mấ
ǹtsĩ̀mã́
ànî̀nmá
k $^{\mathbf{w} a ̀ a ́ n s i ́ m a ̃ ~}$
Ill-formed
*obenba
$*_{\text {ntsenba }}$
*ahenba
*kwanseba/kwansewa

(32) Failure of nasal assimilation in Fante
$\underline{\text { Base forms }}$
a. nyán + bá
nyanba
Derived form
$\underline{\text { Ill-formed }}$
b. gyàǹ + bá
gyanba
jẫñ bá
*nyamma
đàǹ̀bá/đààbá
*gyamma

From the examples above on the Fante female family-name formation, it becomes complicated to phonologically account for the derivational process in the Fante dialect.

It is therefore concluded, based on the discussions made thus far, that the $b$ softening process, which leads to glide formation, is very robust and systematic in the Asante dialect, while it is virtually non-applicable in typical Akuapem derived female family-names. I use the qualification 'typical' in reference to an earlier explanation that what seemed to be the exceptional case of the non-application of the lenition rule [oforiwaa] seems not to be a derivation from a typical Akuapem male family-name. In Fante, however, it is non-systematic; in the same context, it sometimes applies while it fails to apply in some other times.

In sonority theory, it can be concluded that the sonority of initial $b$-increases through both the glide formation and the nasal assimilation in the Asante dialect and to some extent, in the Fante dialect as well.

What is of interest though is how the glide formation ensues: a stop becoming a glide intervocalically is well attested cross-linguistically and therefore phonologically straightforward to explain, but a stop becoming a glide before a nasal consonant is what is not phonologically easily attested other than one espousing markedness reduction theory. 
As has been indicated already in the present paper, diachronic information will be essential in explaining such phenomenon generally.

\section{Conclusion}

This paper has analysed the formation of some female family-names among the Akan people of Ghana. It has been shown that in the derivation process, three major phonological processes ensue in addition to the systematic morphological process of compounding. These phonological processes are lenition or b-softening, and nasalization. In deriving or forming a female family-name, an underlying /-báá/, which has two main contextually-defined variants or allomorphs [-waa] and [-maa] in the Asante dialect, has been posited in this paper. It has been concluded that the underlying morpheme-initial plosive /b/never surfaces in the Asante dialect. And with regard to the Akuapem dialect, the same morpheme-initial stop has been shown to resist any such phonological alternations hence, the morpheme-initial /b/never changes. Finally, for the Fante dialect, it was concluded that the neutralization or otherwise of the initial stop is optional and highly context-defined. It has also claimed in this paper that contrary to the common view in existing literature postulating a common underlying female morpheme for deriving female personal names i.e. both day-names and family-names in Akan, the underlying /-baa, -bea/ and /-ba/ have independent forms as well as functions in the Twi dialects. It is only in the Fante dialect that posits a common underlying form for the derivation of names that indicate 'female' and 'diminution'.

Having said all these, it is worth pointing out that there are some female family-

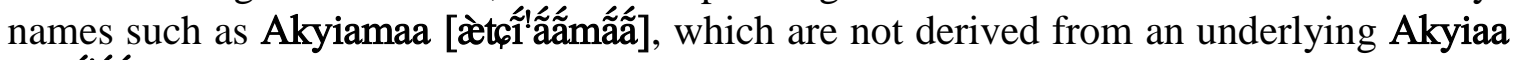
[æ̀tı́1'ãá]; itself an exclusively female name. From this, the learnability implication is that the learner cannot tell from hindsight, given any male family-name, what the derived female counterpart would be. On the other hand, determining a male family-name from a given derived female family-name is comparatively more straightforward. However, that also comes with its challenge, namely that there are also few male family-names which resemble derived female family-names in form. Some of these names are Asianowaa, Nsowaa, Twenewaa etc. among Twi speakers, which are not necessarily derived from the underlying names *Asiano, *Nso(n), *Twene, etc. Similarly, there are also Fante male names such as Entsiwa, Obuesiwa, which are not derived from *Entsi, *Obuesi respectively. There are two possible cognitive implications for the patterns discussed so far: (a) how does the learner know which male family-names are derivable and which ones 
are not? (b) How then does the learner distinguish between family-names which bear the allomorphs [-waa], [-maa], [-a] in Twi on the one hand, and [-ba], [-ma], [-wa] in the Fante, on the other hand, as truly derived female family-names and those that carry similar allomorphs but are not necessarily derived family-names (both male and female names)? A possible solution to these problems may reside perhaps in the lexicon. It has to do with the lexicon- memorization. In the lexicon, all those derivable family-names might be specified for [+derivative] while those that cannot be derived are assigned the feature value [-derivative].

So far what I have attempted to do in this paper is to simply provide an account for some female family-names which are derived from the [+derivative] male family-names in Akan. Thus, it will be a straightforward task for the learner to determine a possible male family-name source from a derived female family-name than the other way around. This is so because as was shown earlier in this paper, there are a lot of family-names which are [+derivative]. However, given any Akan male family-name that is [+derivative] out of which a female counterpart is to be derived, there is a continuum of challenge in accounting for how the female morpheme-initial/-b/ manifests itself among the three major dialects. While the Akuapem dialect presents the most straightforward task on the one end of the continuum, the Fante dialect, at the other end of the continuum, presents the most complicated challenge for doing so. The Asante dialect, on the other hand, occupies the midpoint. 


\section{References}

Abakah, Emmanuel N., 2004. Elision in Fante. Africa \& Asia 4: 181-213.

Adomako, Kwasi, 2015. Truncation of some Akan personal names. GEMA Online Journal of Language Studies 15.1: 143-162.

Agyekum, Kofi, 2006. The sociolinguistic of Akan personal names. Nordic Journal of African Studies 15.2: 206-235.

Ansu-Kyeremeh, Kwasi, 2000. Communicating nominatim: Some social aspects of Bono personal names. Research Review New Series16.2: 19-33.

Appah, Clement K.I. \& Nana A.A. Amfo, 2011. The morphopragmatics of the diminutive morpheme (-ba/-wa) in Akan. Lexis, 6: "Diminutives and Augmentatives in the languages of the world": 85-103.

Boadi, Lawrence A., 2009. A comparative phonological study of some verbal affixes in seven VoltaComoe languages of Ghana. Accra: Black Mask Ltd.

Boadi, Lawrence A., 1984. How to derive Araba and Abenaa from a common underlying representation: Some comments on historical methodology. Anthropological Linguistics 26.4: 435-444.

Braun, Maria, 2009. Word-formation and creolisation: The case of early Sranan. Doctoral Dissertation, Universität Siegen.

Brempong, Owusu, 1991. Twi etymology: A study in ethno-linguistics. Research Review NS7.1\&2: 93-110.

Christaller, Johann G., 1933. A dictionary of the Asante and Fante language called Tshi (Chwee, Twi) ( $2^{\text {nd }}$ ed.). Basel: Basel Evangelical Missionary Society.

Crayner, J.B. 1988. Yeehyiahyia oo! Tema: Ghana Publishing Corporation.

Dolphyne, Florence A., 2006. The Akan (Twi-Fante) language: Its sound systems and tonal structure. Accra: Woeli Publishing Services.

Ghana Statistical Service, 2012. 2010 Population and Housing Census: Summary of Final Results. http://www.statsghana.gov.gh/docfiles/2010phc/Census2010_Summary_report_of_final_ results.pdf. [20.06.2012].

Kager, René, 1999. Optimality Theory. Cambridge Textbooks in Linguistics. New York: CUP.

Marantz, Alec, 1982. Re reduplication. Linguistic Inquiry 13.3: 435-482.

McCarthy, John. 2002. A Thematic Guide to Optimality Theory. Cambridge: Cambridge University Press.

McCarthy, John \& Alan Prince, 1995. Faithfulness and reduplicative identity. In Jill Beckman, Suzanne Urbanczyk \& Laura Walsh-Dickey, eds., University of Massachusetts Occasional 
Papers in Linguistics 18: Papers in Optimality Theory. Amherst: GLSA Publications. Pp. 249-384.

McCarthy, John \& Alan Prince, 1994. Emergence of the unmarked: Optimality in Prosodic Morphology. In M. Gonzàlez, ed., Proceedings of the North East Linguistic Society 24: 333-379.

Obeng, Samuel G., 2001. African anthroponymy: An ethnopragmatic and morphophonological study of personal names in Akan and some African societies. Munich, Germany: Lincom Europa.

Obeng, Samuel G., 1997. From morphophonology to sociolinguistics: The case of Akan hypocoristic day-names. Multilingua -Journal of Cross-Cultural and Interlanguage Communication 16.1: 39-56.

Ossei-Akoto, Baafour. 2008. Akans and their names. http://www.abibitumikasa.com/forums/archive/index.php/t-36536.html [24/07/15].

Prince, Alan \& Paul Smolensky. 1993. Optimality Theory: Constraint Interaction in Generative Grammar. ROA version, 8/2002.

Welmers, William E., 1946. A descriptive grammar of Fanti. Language (Language Dissertation no. 39) 22.3: 3-78. 